\title{
Genetic Diversity in Different Populations of Artemisia absinthium Linn. from Kashmir Himalaya
}

\author{
Reyaz Ahmad Malik*, R. C. Gupta and Santosh Kumari \\ Department of Botany Punjabi University, Patiala 147002, India
}

Received April 11, 2010; accepted June 29, 2010

\begin{abstract}
Summary The present study revealed the varied frequencies of natural chromosomal abnormalities in 4 populations of Artemisia absinthium Linn. collected from different altitudes of Kashmir Himalaya. All the populations are diploid showing $n=9$ with abnormal meiotic behaviour like quadrivalent formation at diakinesis, cytomixis at early prophase-I and laggards at telophases, resulting into reduced pollen fertility. Besides the heterogeneous sized pollen grains, occasionally inter pollen channels were also observed.
\end{abstract}

Key words Artemisia absinthium, Genetic diversity, Kashmir Himalaya, Cytomixis.

Artemisia absinthium in India is mostly distributed in the Himalayan belt. In Kashmir it grows at an altitude from about $1800 \mathrm{~m}$ to $3000 \mathrm{~m}$ (Kaul 1986). There are 20 species of the genus Artemisia occurring in this region (Kaul and Bakshi 1984, Dar et al. 2002).

A. absinthium Linn, commonly called worm wood, is herbaceous, perennial and a medicinally important plant. In Kashmir it is called "Tethwen" by the local people has immense medicinal properties like anti-helminth, vermifuge, as an emenagogue, anti-inflammatory, increases uterine circulation and treats gastritis (Lustin 1979). The active principles present in this species are essential oils (thujon and thujol), sesqueterpenes, absinthin, terpenoids and flavinoids that are known to increase the secretion of gastric acid pepsin and pancreatic juice (Khare 2004). Its extracts have also been proved to have free radical scavenging activity (Canadanovic-Burnet et al. 2005) and an influence on osmotic stability of human erythrocytes (de Frietas et al. 2008).

Keeping in view the various important medicinal properties of this species, the present study is undertaken on population basis in order to mark out the genetic diversity among different populations collected from different altitudinal sites.

\section{Materials and methods}

Meiotic studies were carried out in young floral buds fixed in Carnoy's fixative using standard acetocarmine smearing technique. Pollen fertility was estimated by their stainability in $1 \%$ glyceroacetocarmine. Well-filled and well-stained pollen grains were regarded as fertile while the shrunken and unstained pollen grains were considered as sterile.

\section{Results and discussion}

Presently meiotic studies have been made on 4 different populations covering different altitudinal ranges of Kashmir Himalaya (Table 1). All 4 populations are found to be diploid with $n=9$ (Figs. 1-3) and show various meiotic abnormalities. The meiotic abnormalities observed include multivalent formation at diakinesis, cytomixis at early prophase-I and laggard formation at

\footnotetext{
*Corresponding author, e-mail: malik_reyaz@rediffmail.com
} 
Table 1. Population number with site of collection, altitude in meters (m), chromosome no. (n) and ploidy level of 4 populations of A. absinthium

\begin{tabular}{|c|c|c|c|c|}
\hline $\begin{array}{l}\text { Population } \\
\text { number }\end{array}$ & Collection site & Altitude & $\begin{array}{c}\text { Haploid } \\
\text { chromosome No. }\end{array}$ & Ploidy level \\
\hline $\mathrm{P}-1$ & Dalgate, Hillock (Srinagar) & $1750 \mathrm{~m}$ & 9 & $2 \mathrm{x}$ \\
\hline $\mathrm{P}-2$ & Tral, Karmullah (Pulwama) & $1850 \mathrm{~m}$ & 9 & $2 \mathrm{x}$ \\
\hline $\mathrm{P}-3$ & Kellar (Shopian) & $2000 \mathrm{~m}$ & 9 & $2 \mathrm{x}$ \\
\hline P-4 & Aharbal (Kulgam) & $2600 \mathrm{~m}$ & 9 & $2 \mathrm{x}$ \\
\hline
\end{tabular}

Table 2. Data on meiotic course and pollen fertility in 4 populations of A. absinthium

\begin{tabular}{ccccccc}
\hline \hline \multirow{2}{*}{$\begin{array}{c}\text { Population } \\
\text { number }\end{array}$} & $\begin{array}{c}\text { \% of PMCs with } \\
\text { quadrivalent }\end{array}$ & $\begin{array}{c}\text { \% of PMCs } \\
\text { involved }\end{array}$ & $\begin{array}{c}\text { No. of PMCs } \\
\text { connected }\end{array}$ & $\begin{array}{c}\text { Cytomixis } \\
\text { with laggards at } \\
\text { T-I and T-II }\end{array}$ & $\begin{array}{c}\text { \% of pollens } \\
\text { showing } \\
\text { channels }\end{array}$ & $\begin{array}{c}\text { Pollen } \\
\text { fertility } \\
\% \text { age }\end{array}$ \\
\hline P-1 & $0.00(0 / 247)$ & $00.00(0 / 220)$ & 0 & $0.00(0 / 240)$ & $0.00(0 / 226)$ & 91.80 \\
P-2 & $0.00(0 / 251)$ & $02.94(6 / 204)$ & 2 & $0.00(0 / 245)$ & $0.00(0 / 232)$ & 87.00 \\
P-3 & $0.80(2 / 248)$ & $10.55(19 / 180)$ & $2-3$ & $3.44(8 / 232)$ & $0.00(0 / 220)$ & 75.86 \\
P-4 & $1.95(4 / 205)$ & $10.60(21 / 198)$ & $2-3$ & $5.80(13 / 224)$ & $1.92(4 / 208)$ & 73.21 \\
\hline
\end{tabular}

Figures in parentheses denote observed number of abnormal PMCs/pollens in numerator and total number of PMCs/pollens in denominator.

telophase-I and telophase-II, resulting in reduced pollen fertility. Interestingly, there are interpopulation differences in the meiotic abnormalities (Table 2).

At diakinesis, one quadrivalent (Fig. 2) in few PMCs was observed in 2 populations viz. P-3 and P-4 (Table 1) whereas in the other 2 populations no PMC with quadrivalents was observed. However, the frequency of PMCs with quadrivalents in P-3 is less $(0.80 \%)$ than that in P-4 $(1.95 \%)$. In both these populations the quadrivalent observed is of open chain form that may have arisen due to shorter size of interchanged segments. The presence of such a low frequency of quadrivalents might be indicative of the cryptic type of structural heterozygosity. According to Levin (2002), reduced pollen fertility is also as a result of structural heterozygosity. Though the species has been already worked out by researchers including Khoshoo and Sobti (1958), Koul (1964, 1965), Bhat et al. (1974), and Kaul and Bakshi (1984), no one has yet reported the multivalent formation in this species.

Presently, the cytomixis is reported in the 3 populations viz. P-2, P-3 and P-4, but is found to be absent in $\mathrm{P}-1$. As such there is no earlier report of cytomixis in $A$. absinthium. Further the frequency and the number of PMCs involved in cytomixis also varies in different populations (Table 2 ). It is seen that generally the cytomixis involves a varied number of PMCs (2-3) and are mostly observed at early prophase-I (Figs. 4-5). However no PMC with hyperploidy or hypoploidy has been observed. The phenomenon of cytomixis is referred to be due to various factors, such as the physiological (Bahl and Tyagi 1988), temperature (Narain 1976), stress factors coupled with genetic control (Ghanima and Talaat 2003), and direct genetic control (Bellucci et al. 2003, Haroun et al. 2004). Some of the recent reports of cytomixis prevalent in plants from India include that of Lattoo et al. (2006), Singhal et al. (2007) and Singhal and Kumar (2008). According to some of the workers like Levan (1941), Zheng et al. (1987), Ghanima and Talaat (2003) and Kim et al. (2009), cytomixis plays a major role in chromosomal diversity and speciation of taxa. As per Bhat et al. (2006), the extra chromatin mass received by one PMC from other during cytomixis can also form micronuclei or micro pollen in the later stages. 

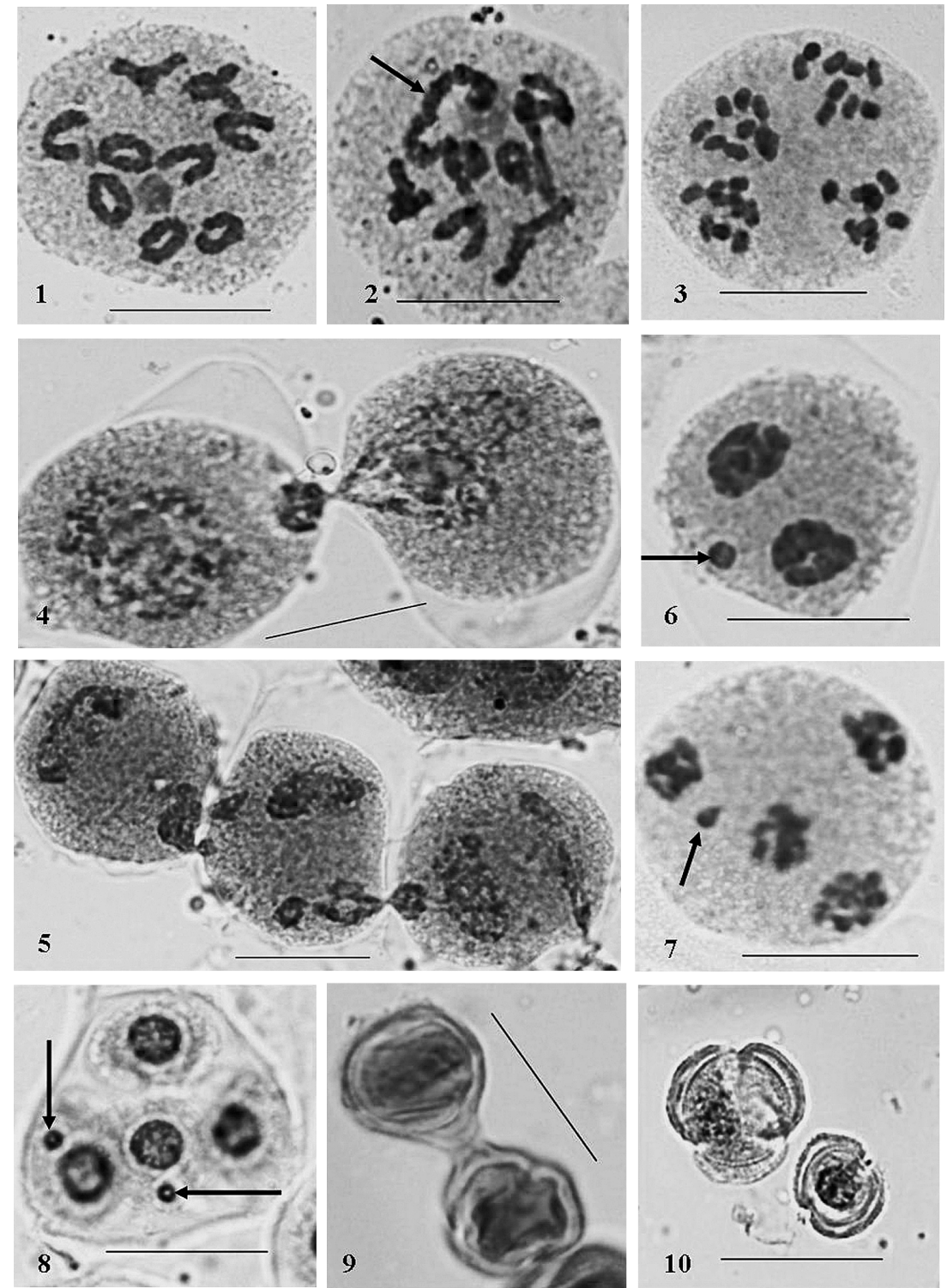

Figs. 1-10. 1. PMC at diakinesis with 9 bivalents. 2. PMC at diakinesis with 1 quadrivalent(arrow). 3. PMC at Anaphase-II. 4. Cytomixis involving 2 PMCs. 5. Cytomixis involving 3 PMCs. 6. PMC with a laggard at Telophase-I (arrow). 7. PMC with a laggard at early Telophase-II (arrow). 8. Tetrad with 2 micronuclei (arrows). 9. Two pollen grains connected through a channel. 10. Heterogeneous sized pollen grains (bar $=10 \mu \mathrm{m})$.

Consequent to the meiotic abnormality laggards have also been observed. Though in low frequencies, laggards were observed during T-I (Fig. 6) and early T-II (Fig. 7) only in the populations from P-3 (3.44\% PMCs) and P-4 (5.80\% PMCs) whereas in the other 2 populations no PMC has been observed with laggards. These laggards might have later on formed the micronuclei (Fig. 8).

The post-meiotic consequences, such as reduced pollen fertility, the production of heterogeneous sized pollen grains (Fig. 10) and inter-pollen channels, are the result of the abnormalities discussed above. Hence, population P-1 shows the highest frequency of fertile pollen 
grains (91.81\%) and population P-4 shows the lowest pollen fertility (73.21\%) among the 4 populations studied. Further the inter-pollen channel-like structures are observed only in the P-4 population, with a low frequency $(1.92 \% \mathrm{PMCs})$, and not more than 2 pollens are seen involved per group (Fig. 9).

From the above discussion it appears that there is some correlation in the frequency of meiotic abnormalities with the altitudinal distribution of the species and these might have been induced due to harsh environmental conditions.

\section{Acknowledgements}

Authors acknowledge University Grants Commission, New Delhi for providing financial assistance under SAP, ASIST (U.G.C) and FIST (DST).

\section{References}

Bhat, B. K., Bakshi, S. K. and Kaul, M. K. 1974. IOPB chromosome number reports XLVI. Taxon 25: 809.

Bhat, T. A., Parveen, S. and Khan, A. H. 2006. MMS-induced cytomixis in pollen mother cells of broad bean (Vicia faba L.). Turk. J. Bot. 30: 273-279.

Bahl, J. R. and Tyagi, B.R. 1988. Cytomixis in pollen mother cell of Papaver dubium L. Cytologia 53: 469-474.

Bellucci, M., Roscini, C. and Mariani, A. 2003. Cytomixis in pollen mother cells of Medicago sativa L. J. Heredity 94: 512-516.

Canadanovic-Burnet, J. M., Djilas, S. M. and Cetkovic, G. S. 2005. Free radical scavenging activity of wormwood (Artemisia absinthium L.) extracts. J. Sci. Food Agric. 85: 265-272.

Dar, G. H, Bhagat, R. C, and Khan, M. A. 2002. Biodiversity of the Kashmir Himalaya. Anmol Publications, New Delhi.

de Frietas, M. V., Netto, R. C. and da Costa Huss, J. C. 2008. Influence of aqueous crude extracts of medicinal plants on the osmotic stability of human erythrocytes. Toxicol In Vitro 22: 219-224.

Ghanima, A. M. and Talaat A. A. 2003. Cytomixis and its possible evolutionary role in a Kuwait population of Diplotaxis harra (Boraginaceae). Bot. J. Linn. Soc. 143: 169-175.

Haroun, S. A., Al Shehri, A. M. and Al Wadie, H. M. 2004. Cytomixis in the microsporogenesis of Vicia faba L. (Fabaceae). Cytologia 69: 7-11.

Kaul, M. K. 1986. Weed flora of Kashmir valley. Scientific Publishers, Jodhpur, India.

— and Bakshi, S. K. 1984. Studies on the genus Artemisia L. in North West Himalaya with particular reference to Kashmir. Folia Geobot. et Phytotax. 19: 299-316.

Kim, J. S., Oginuma, K and Tobe, H. 2009. Syncyte formation in the microsporangium of Chrysanthemum (Asteraceae): a pathway to infraspecific polyploidy. J. Plant Res. 122: 439-444.

Khare, C. P. 2004. Indian Herbal Remedies. Rational Western Therapy, Ayurvedic and Other Traditional Usage, Botany. Springer-Verlag, Berlin.

Khoshoo, T. N. and Sobti, S. N. 1958. Cytology of Indian species of Artemisia. Nature 181: 853-854.

Koul, M. L. H. 1964. Cytogenetics of polyploids? I. Cytology of A. vulgaris L.? Cytologia 29: 407-414.

- 1965. Gene-ecological studies in A. vulgaris L.? J. Sci. Res. Banarus Hindhu Univer. 15: 104-119.

Lattoo, S. K., Khan, S., Bamotra, S. and Dhar, A. K. 2006. Cytomixis impairs meiosis and influences reproductive success in Chlorophytum comosum (Thunb) Jacq.- an additional strategy and possible implications. J. Biosci. 31: 629-637.

Levan, A. 1941. Syncyte formation in the pollen mother cells of haploid Phleum pratense. Hereditas 27: $243-253$.

Levin, D. A. 2002. The Role of Chromosomal Change in Plant Evolution. Oxford University Press, New York.

Lust, J. 1979. The Herb Book. Bantam Books, New York.

Narain, P. 1976. Cytomixis in pollen mother cells of Hemerocallis Linn. Curr. Sci. 48: 996-998.

Singhal, V. K. and Kumar, P. 2008. Impact of cytomixis on meiosis, pollen viability and pollen size in wild populations of Himalayan poppy (Meconopsis aculeate Royle). J. Biosci. 33: 371-380.

- Gill, B. S. and Dhaliwal, R. S. 2007. Status of chromosomal diversity in the hardwood tree species of Punjab state. J. Cytol. Genet. 8: 67-83.

Zheng, G. C., Yang, Q. and Zheng, Y. 1987. The relationship between cytomixis, chromosome mutation and karyotype evolution in Lily. Caryologia 40: 243-259. 